\title{
Compromised fertility disrupts Peg1 but not Snrpn and Peg3 imprinted methylation acquisition in mouse oocytes
}

\section{Michelle M. Denomme $e^{1,2,3}$, Carlee R. White ${ }^{1,2,3}$, Carolina Gillio-Meina ${ }^{1,4}$, William A. MacDonald ${ }^{1,2}$, Bonnie J. Deroo ${ }^{1,2,3,5}$, Gerald M. Kidder ${ }^{1,4}$ and Mellissa R. W. Mann ${ }^{1,2,3}$ *}

${ }^{1}$ Children's Health Research Institute, London, ON, Canada

${ }^{2}$ Department of Obstetrics and Gynaecology, Schulich School of Medicine and Dentistry, University of Western Ontario, London, ON, Canada

${ }^{3}$ Department of Biochemistry, Schulich School of Medicine and Dentistry, University of Western Ontario, London, ON, Canada

${ }^{4}$ Department of Physiology and Pharmacology, Schulich School of Medicine and Dentistry, University of Western Ontario, London, ON, Canada

${ }^{5}$ Department of Oncology, Schulich School of Medicine and Dentistry, University of Western Ontario, London, ON, Canada

\section{Edited by:}

Wendy Robinson, University of British Columbia, Canada

\section{Reviewed by:}

Sushma S. lyengar, University of Southern California, USA

Ursula Eichenlaub-Ritter, University of Bielefeld, Germany

\section{${ }^{*}$ Correspondence:}

Mellissa R. W. Mann, Children's Health Research Institute, 4th Floor, Victoria Research Laboratories, A4-130a, 800 Commissioners Road East, London, ON, Canada N6C 2V5. e-mail:mmann22@uwo.ca
Growth and maturation of healthy oocytes within follicles requires bidirectional signaling and intercellular gap junctional communication. Aberrant endocrine signaling and loss of gap junctional communication between the oocyte and granulosa cells leads to compromised folliculogenesis, oocyte maturation, and oocyte competency, consequently impairing fertility. Given that oocyte-specific DNA methylation establishment at imprinted genes occurs during this growth phase, we determined whether compromised endocrine signaling and gap junctional communication would disrupt de novo methylation acquisition using ER $\beta$ and connexin37 genetic models. To compare mutant oocytes to control oocytes, DNA methylation acquisition was first examined in individual, 20-80 $\mu \mathrm{m}$ control oocytes at three imprinted genes, Snrpn, Peg3, and Peg1. We observed that each gene has its own size-dependent acquisition kinetics, similar to previous studies. To determine whether compromised endocrine signaling and gap junctional communication disrupted de novo methylation acquisition, individual oocytes from Esr2and Gja4-deficient mice were also assessed for DNA methylation establishment. We observed no aberrant or delayed acquisition of DNA methylation at Snrpn, Peg3, or Peg1 in oocytes from Esr2-deficient females, and no perturbation in Snrpn or Peg3 de novo methylation in oocytes from Gja4-null females. However, Gja4 deficiency resulted in a loss or delay in methylation acquisition at Peg1. One explanation for this difference between the three loci analyzed is the late establishment of DNA methylation at the Peg1 gene. These results indicate that compromised fertility though impaired intercellular communication can lead to imprinting acquisition errors. Further studies are required to determine the effects of subfertility/infertility originating from impaired signaling and intercellular communication during oogenesis on imprint maintenance during preimplantation development.

Keywords: genomic imprinting, DNA methylation, imprint acquisition, infertility, oocyte, connexin37, estrogen receptor beta, oocyte diameter

\section{INTRODUCTION}

The tight regulation of monoallelic gene expression based on gametic origin is termed genomic imprinting (Bartolomei and Ferguson-Smith, 2011). This dynamic process relies on epigenetic modifications such as DNA methylation to mark, or "imprint", one of the two parental alleles, resulting in differential gene expression in progeny (Verona et al., 2003). Gametogenesis encompasses the critical period of heritable epigenetic reprogramming for imprinted genes. Imprinted DNA methylation is first erased in primordial germ cells, subsequently allowing for de novo differential methylation at imprinted loci in oocytes and sperm ( $\mathrm{Li}$ and Sasaki, 2011). In males, de novo DNA methylation acquisition occurs during the prenatal stages of spermatogenesis, beginning in prospermatogonia and is completed by birth (Kafri et al., 1992; Davis et al., 1999, 2000; Ueda et al., 2000). In females, de novo DNA methylation is acquired after oocytes enter the growth phase of follicular development, from the primary to antral follicle stage (Lucifero et al., 2004; Hiura et al., 2006; Sato et al., 2007; Song et al., 2009). Importantly for oocytes, imprinted methylation acquisition is dependent on oocyte size and not oocyte age, with methylation levels increasing as oocyte diameter increases.

The correct establishment of germline imprints is significant as disruptions to this process can result in the development of imprinting disorders such as Beckwith-Wiedemann syndrome (BWS), Silver-Russell Syndrome (SRS), and Angelman syndrome (AS). BWS is an overgrowth disorder that is caused by imprinting 
defects that result in a gain of maternal methylation at the H19 imprinting control region (ICR) or a loss of maternalspecific methylation at the KCNQ1OT1 (KCNQ1 overlapping transcript 1) ICR (Weksberg et al., 2010). SRS is an intrauterine growth restricted imprinting disorder with imprinting defects at the H19 and possibly at the paternally expressed gene 1 (Peg1) imprinted domains (Eggermann, 2010). AS is a neurological disorder that is caused by loss of maternal-specific methylation at the small nuclear ribonucleoprotein N (SNRPN) ICR (Mabb et al., 2011). Sporadic epigenetic errors resulting in these disorders are reported to occur more frequently in the assisted reproductive technologies (ARTs) population (Cox etal., 2002; DeBaun et al., 2003; Gicquel etal., 2003; Maher et al., 2003; Orstavik et al., 2003; Halliday et al., 2004; Chang et al., 2005; Ludwig et al., 2005; Rossignol et al., 2006; Azzi et al., 2009; Bliek et al., 2009; Lim et al., 2009; Lennerz et al., 2010; Turner et al., 2010). For AS, patients at the highest risk for an imprinting defect have parents with prolonged infertility undergoing infertility treatment (Ludwig et al., 2005; Doornbos et al., 2007). This raises the question as to whether imprinting errors in ART patients are associated with parental infertility/subfertility. While studies have been conducted to determine the effects of ARTs on genomic imprinting, investigations of how impaired fertility may contribute to imprinting errors are lacking. In this study, we queried whether impaired fertility arising during oogenesis could lead to imprinting defects.

Development of healthy oocytes is dependent on interactions between the growing oocyte and surrounding follicular cells (Kidder and Vanderhyden, 2010). Oocytes play an important role in regulating granulosa cell development, proliferation, and differentiation, as well as steroid hormone production. In turn, follicular cells play a critical role in oocyte growth, meiotic progression, and transcriptional activity and chromatin remodeling of the oocyte genome. This synergistic partnership is facilitated by endocrine and paracrine signaling, and intercellular gap junctional communication, ensuring meiotic and developmental competence of the oocyte. In this study, we specifically examined the effects of aberrant signaling and communication on imprint acquisition.

A complex endocrine signaling pathway is active in the ovary that regulates follicle and oocyte development. $17 \beta$-estradiol acting through nuclear estrogen receptor beta $(\mathrm{ER} \beta)$ augments the actions of follicle stimulating hormone (FSH). In the ovary, ER $\beta$ is expressed primarily in granulosa cells and at low levels in the oocyte (Drummond and Fuller, 2011). Female mice bearing a targeted deletion of the ER $\beta$ (Esr2) gene are subfertile, producing fewer oocytes following superovulation, as well as litters with fewer pups (Krege et al., 1998; Couse et al., 2000, 2003, 2005; Dupont et al., 2000; Emmen et al., 2005). Attenuated differentiation of granulosa cells following gonadotropin stimulation in Esr2-null mice leads to decreased antrum formation, delayed follicle maturation, and reduced follicular rupture, producing greater numbers of atretic follicles and fewer preovulatory oocytes. In addition, vascularization of the thecal layer, which is required for follicular growth, is impaired (Inzunza et al., 2007). Mechanistically, $\mathrm{ER} \beta$ is required for optimal cAMP production in mouse granulosa cells following gonadotropin stimulation (Deroo et al., 2009).
ER $\beta$ deficiency causes disruption of cAMP second messenger signaling in granulosa cells in response to $\mathrm{FSH}$, producing aberrant FSH-regulated gene expression, decreased response to luteinizing hormone, and impaired ovulation and fertility.

Gap junctions are specialized channels composed of six membrane proteins termed connexins (CX). These channels are essential for communication between neighboring cells (Harris, 2001). In the mouse, CX37 and CX43 are the only connexins known to be required in developing follicles (Kidder and Vanderhyden, 2010). CX43 localizes to gap junctions in the granulosa cell membranes, enabling granulosa cell to granulosa cell communication. By comparison, CX37 constitutes the gap junctions coupling the oocyte with surrounding granulosa cells and is specifically located at the interface between the oocyte and the first layer of granulosa cells (Simon et al., 1997). Gap junctions allow the transport of nutrients, metabolites and second messengers, such as cAMP, between the granulosa cells and the oocyte (Kidder and Vanderhyden, 2010). Targeted deletion of the CX37 (Gja4) gene causes arrested folliculogenesis at the early antral stage, impaired oocyte development and meiotic competency, and premature luteinization of the follicles (Simon et al., 1997; Carabatsos et al., 2000).

In this study, we employed the Esr2-/- and $\mathrm{Gja}^{-/-}$genetic models to interfere specifically with endocrine signaling and gap junctional communication, compromising fertility. We hypothesized that inhibition of the ER $\beta$ pathway and/or oocyte-granulosa cell gap junctional communication would lead to perturbations in imprinted methylation acquisition. To compare mutant oocytes to control oocytes, DNA methylation acquisition was first examined in individual, 20-80 $\mu \mathrm{m}$ diameter control oocytes at three imprinted genes, Snrpn, Peg3, and Peg1 (also known as Mest). Similar to previous studies (Lucifero et al., 2004; Hiura et al., 2006; Sato et al., 2007; Song et al., 2009), we observed that each gene had its own size-dependent acquisition kinetics. To determine whether compromised endocrine signaling and gap junctional communication disrupted de novo methylation acquisition, preovulatory oocytes from Esr $2^{-/-}$females, and early antral stage oocytes from $\mathrm{Gja4}^{-1-}$ mice were assessed for DNA methylation establishment at Snrpn, Peg3, and Peg1. We observed no aberrant or delayed acquisition of DNA methylation at Snrpn, Peg3, and Peg1 in preovulatory oocytes from ER $\beta$-deficient females. Similarly, we found no perturbation of Snrpn and Peg3 de novo methylation in oocytes from CX37-null follicles. However, Peg1 methylation acquisition was lost or delayed in Gja4-deficient oocytes compared to controls. We attribute this to the late establishment of DNA methylation at the Peg1 gene. These results indicate that compromised fertility though impaired intercellular communication can lead to imprinting acquisition errors. Further studies are required to determine the post-fertilization effects of subfertility/infertility originating from impaired signaling and intercellular communication during oogenesis.

\section{MATERIALS AND METHODS OOCYTE ISOLATION \\ Control oocyte collections}

Ovaries were obtained from C57BL/6 female mice (Charles River) at $10,14,21$, and 28 days postpartum (dpp), and placed in Waymouth MB 752/1 medium (Invitrogen) supplemented with 
$10 \%$ fetal bovine serum (Li et al., 2007). For further follicle separation, ovaries were digested in the same medium containing $2 \mathrm{mg} / \mathrm{ml}$ type I collagenase (Sigma-Aldrich) at $37^{\circ} \mathrm{C}$. Primary, secondary and early tertiary (antral) follicles were liberated by repeated aspiration and expulsion with a $1 \mathrm{ml}$ pipette. Follicles were washed several times in culture medium without collagenase. For oocyte isolation, follicles were centrifuged for $5 \mathrm{~min}$ at 4,000 rpm, re-suspended and digested in 0.05\% Trypsin/EDTA in a culture dish for $15 \mathrm{~min}$ at $37^{\circ} \mathrm{C}$. Oocytes were dissociated from the granulosa cells by repeated aspiration and expulsion with a $1 \mathrm{ml}$ pipette. Oocytes were retrieved through mouth pipetting and placed in $30 \mu \mathrm{l}$ drops of M2 medium (Sigma) for further analysis.

\section{Gja4-null oocyte collections}

Ovaries were removed from $\mathrm{Gja}^{-/-}$female mice (C57BL/6 background) at 21 and $28 \mathrm{dpp}$, and placed in Waymouth MB 752/1 medium (Invitrogen) supplemented with $10 \%$ fetal bovine serum. Gja4-null oocytes were retrieved through the same collection method as control oocytes and placed in $30 \mu 1$ M2 medium (Sigma) for further analysis.

\section{Esr2-null oocyte collections}

Ovaries were removed from Esr $2^{-/-}$females (C57BL/6 background) at $28 \mathrm{dpp}$ and placed in a $100-\mathrm{mm}$ cell culture dish containing $15 \mathrm{ml}$ ice-cold M199 medium (Sigma) supplemented with $1 \mathrm{mg} / \mathrm{ml} \mathrm{BSA} \mathrm{(Invitrogen)} \mathrm{and} 2.5 \mathrm{~g} / \mathrm{ml}$ gentamicin (Invitrogen; Deroo et al., 2009). Follicles were released by manual puncture with 25-gauge needles and subsequent pressure applied with a sterile spatula. Oocytes were retrieved through mouth pipetting and transferred to $30 \mu \mathrm{l}$ drops of M2 medium (Sigma) for further analysis.

\section{Single oocyte bisulfite mutagenesis and sequencing}

Processing, embedding, and bisulfite mutagenesis of individual oocytes was performed as previously described (Denomme et al., 2011). Briefly, oocytes were treated with $0.3 \mathrm{mg} / \mathrm{ml}$ hyaluronidase (Sigma) to remove any surrounding cumulus cells (if present), washed three times in $30 \mu \mathrm{l}$ drops of M2 medium (Sigma), and then imaged using the Olympus IX81 microscope. Oocyte diameter was measured using Macnification v.1.8 (Orbicule). Following treatment with acidic Tyrode's solution (Sigma) to remove the zona pellucida (if present), oocytes were washed twice in M2 medium, then individual oocytes were embedded in $10 \mu \mathrm{l}$ of 2:1 LMP agarose and lysis solution [100 mM Tris- $\mathrm{HCl}, \mathrm{pH} 7.5$ (Bioshop), 500 mM LiCl (Sigma), 10 mM EDTA, pH 8.0 (Sigma), 1\% LiDS (Bioshop), and $5 \mathrm{mM}$ DTT (Sigma), 1 l $2 \mathrm{mg} / \mathrm{ml}$ proteinase K (Sigma), and $1 \mu \mathrm{l}$ 10\% Igepal (Sigma)] under $300 \mu \mathrm{l}$ of mineral oil (Sigma), and placed on ice for $10 \mathrm{~min}$ for the agarose to harden. Mineral oil was replaced with $500 \mu \mathrm{l}$ SDS lysis buffer [450 $\mu 11 \times$ Tris EDTA (TE), pH 7.5 [10 mM Tris (Bioshop), $1 \mathrm{mM}$ EDTA], $50 \mu \mathrm{l}$ 10\% SDS (Bioshop), $1 \mu 12 \mathrm{mg} / \mathrm{ml}$ proteinase $\mathrm{K}$ ] and incubated at $50^{\circ} \mathrm{C}$ overnight. Following overnight incubation, lysis buffer was replaced with $300 \mu \mathrm{l}$ mineral oil and oocytes were either immediately treated for bisulfite conversion or frozen at $-20^{\circ} \mathrm{C}$ for up to 5 days. Firstly, samples were placed at $90^{\circ} \mathrm{C}$ for $2.5 \mathrm{~min}$ to heat inactivate the proteinase $\mathrm{K}$, and then DNA was denatured using $0.1 \mathrm{M} \mathrm{NaOH}$ (Sigma) at $37^{\circ} \mathrm{C}$ for $15 \mathrm{~min}$. Treatment with $2.5 \mathrm{M}$ bisulfite solution (0.125 M hydroquinone (Sigma), 3.8 g sodium hydrogen sulfite (Sigma), $5.5 \mathrm{ml}$ water, and $1 \mathrm{ml} 3 \mathrm{M} \mathrm{NaOH}$ ) at $50^{\circ} \mathrm{C}$ for $3.5 \mathrm{~h}$ was followed by desulfonation using $0.3 \mathrm{M} \mathrm{NaOH}$ at $37^{\circ} \mathrm{C}$ for $15 \mathrm{~min}$. Samples were washed twice in $1 \times \mathrm{TE} \mathrm{pH} 7.5$ and twice in water, and then added directly to a Ready-To-Go PCR bead (GE) consisting of $15 \mu \mathrm{l}$ water, gene-specific primers and $1 \mu \mathrm{l}$ of $240 \mathrm{ng} / \mathrm{ml}$ transfer RNA as a carrier, with $25 \mu \mathrm{l}$ mineral oil overlay. Negative controls (no oocyte) were processed alongside each bisulfite reaction. PCR amplification of the Snrpn ICR, Peg3 DMR, and Peg1 DMR was performed as previously described (Market-Velker et al., 2010). Following ligation into the PGEM-T easy vector (Promega) and cloning, $30 \mu \mathrm{l}$ of colony PCR product was sent to Bio-Basic Inc. (Markham, Ontario, Canada) for sequencing. For each sample, five clones were sequenced. As MI oocytes have not extruded the first polar body, both alleles were successfully amplified in some oocytes, and only one allele was detectable in other oocytes. However, oocytes with more than two clones having very different methylation patterns and different non-CpG conversion rates were excluded from analysis, as cumulus cell contamination could not be ruled out. Table 1 gives the number of oocytes included and excluded from analysis per gene.

\section{STATISTICAL ANALYSIS}

For each imprinted gene, significant difference of CpG methylation percentage was determined by a two-tailed Mann-Whitney $U$ test between mutant oocytes and control oocytes matched for size. A diameter range of 65-80 $\mu \mathrm{m}$ was used to compare Esr2deficient oocytes to control oocytes, while the 35-60 $\mu \mathrm{m}$ diameter range (including KO468 for Snrpn with a diameter of $60.5 \mu \mathrm{m}$ ) was used to compare the Gja4 deficient to control oocytes. A $p$-value of $<0.05$ was taken to be statistically significant.

\section{RESULTS}

\section{METHYLATION ACQUISITION IN CONTROL OOCYTES CORRELATES WITH OOCYTE DIAMETER}

In female mammals, imprinted DNA methylation has been shown to arise during follicle growth from the primary to the antral stage in correlation with oocyte diameter (Lucifero et al., 2004; Hiura et al., 2006), with gene-specific kinetics for imprint acquisition. However, these analyses were performed with pooled oocytes of different sizes. To compare individual mutant oocytes to control oocytes, we first needed to examine imprinted DNA methylation acquisition in individual control oocytes. C57BL/6 oocytes were

\begin{tabular}{|c|c|c|c|c|c|c|c|c|c|}
\hline & \multicolumn{3}{|c|}{ Snrpn } & \multicolumn{3}{|c|}{ Peg3 } & \multicolumn{3}{|c|}{ Peg1 } \\
\hline & IN & EX & \%EX & IN & EX & $\%$ EX & IN & EX & $\%$ EX \\
\hline WT & 55 & 1 & 1.8 & 56 & 6 & 9.7 & 58 & 7 & 11.1 \\
\hline Esr2-1- & 12 & 1 & 7.7 & 11 & 1 & 8.3 & 11 & 1 & 8.3 \\
\hline $\mathrm{Gja}^{-/-}$ & 31 & 5 & 13.9 & 20 & 1 & 4.8 & 31 & 3 & 8.8 \\
\hline Total & 98 & 7 & 6.7 & 87 & 8 & 8.4 & 100 & 11 & 9.9 \\
\hline
\end{tabular}

$I N$, included oocytes with one to two clone patterns; EX, excluded oocytes with 3 or more clone patterns. 
collected at $10,14,21$, and 28 dpp to obtain oocytes with a diameter range of $20-80 \mu \mathrm{m}$. Oocytes that were collected at $10 \mathrm{dpp}$ displayed a diameter range of $20-70 \mu \mathrm{m}$, those at $14 \mathrm{dpp}$ were $40-80 \mu \mathrm{m}$ in diameter, at $21 \mathrm{dpp}$ ranged from 50 to $70 \mu \mathrm{m}$, and at $28 \mathrm{dpp}$ ranged from 60 to $80 \mu \mathrm{m}$ in diameter.

Analysis of de novo methylation acquisition at the Snrpn ICR showed mean methylation levels of $8.7 \%$ in $20-40 \mu \mathrm{m}, 12.6 \%$ in $40-45 \mu \mathrm{m}, 9.3 \%$ in $45-50 \mu \mathrm{m}, 39.3 \%$ in $50-55 \mu \mathrm{m}, 82.7 \%$ in 55-60 $\mu \mathrm{m}, 97.0 \%$ in $60-65 \mu \mathrm{m}, 82.8 \%$ in $65-70 \mu \mathrm{m}, 93.8 \%$ in $70-75 \mu \mathrm{m}$, and $98.0 \%$ in $75-80 \mu \mathrm{m}$ oocytes (Figures 1 and 2). Likewise, mean methylation levels at the Peg3 DMR were 1.6\% in $20-40 \mu \mathrm{m}, 11.2 \%$ in $40-45 \mu \mathrm{m}, 16.1 \%$ in $45-50 \mu \mathrm{m}, 22.9 \%$ in $50-55 \mu \mathrm{m}, 47.5 \%$ in $55-60 \mu \mathrm{m}, 51.7 \%$ in $60-65 \mu \mathrm{m}, 82.6 \%$ in $65-70 \mu \mathrm{m}, 85 \%$ in $70-75 \mu \mathrm{m}$, and $94.0 \%$ in $75-80 \mu \mathrm{m}$ oocytes (Figures 3 and 4). For the Peg1 DMR, mean methylation levels were $4.3 \%$ in $20-40 \mu \mathrm{m}, 4.7 \%$ in $40-45 \mu \mathrm{m}, 12.2 \%$ in $45-50 \mu \mathrm{m}$, $15.9 \%$ in $50-55 \mu \mathrm{m}, 45.5 \%$ in $55-60 \mu \mathrm{m}, 51.6 \%$ in $60-65 \mu \mathrm{m}$, $91.0 \%$ in $65-70 \mu \mathrm{m}, 92.0 \%$ in $70-75 \mu \mathrm{m}$, and $93.2 \%$ in $75-80 \mu \mathrm{m}$ oocytes (Figures 5 and 6). Thus, we observed that each gene had its own acquisition kinetics. DNA methylation acquisition began first for Snrpn at $\sim 50 \mu \mathrm{m}$ and was near completion at $>60 \mu \mathrm{m}$. Next was Peg3, where DNA methylation acquisition was initiated at $\sim 45 \mu \mathrm{m}$ and nearly complete at $>65 \mu \mathrm{m}$, which was followed by Peg1, where DNA methylation acquisition began at $\sim 55 \mu \mathrm{m}$ and was near completion by $>70 \mu \mathrm{m}$. Snrpn had the shortest acquisition interval while Peg3 had the longest.

\section{METHYLATION ACQUISITION IN ER $\beta$-DEFICIENT OOCYTES}

Ovaries deficient in Esr2 produce a reduced number of maturing oocytes, but those that do mature appear to not be developmentally compromised (Krege et al., 1998). Consistent with this, we recovered a small number of oocytes from $28 \mathrm{dpp}$ females, ranging in diameter size from 66 to $82 \mu \mathrm{m}$, corresponding to the preovulatory stage in oocyte growth. To investigate the role of reduced hormone signaling on imprint acquisition, we analyzed the progression of DNA methylation acquisition in developing oocytes from mice deficient in Esr2. For the Snrpn ICR, mean methylation levels were $98.0 \%$ for $65-70 \mu \mathrm{m}, 97.0 \%$ for $70-75 \mu \mathrm{m}$, and $100.0 \%$ for 75-80 $\mu$ m oocytes (Figures 2 and 7). For the Peg3 DMR, mean methylation was $100.0 \%$ in $65-70 \mu \mathrm{m}, 99.4 \%$ in $70-75 \mu \mathrm{m}$, and $98.7 \%$ in $75-80 \mu \mathrm{m}$ oocytes (Figures 4 and 8 ). For the Peg1 DMR, mean methylation levels were $96.5 \%$ for $65-70 \mu \mathrm{m}, 95.1 \%$ for 70 $75 \mu \mathrm{m}$, and $96.5 \%$ for $75-80 \mu \mathrm{m}$ oocytes (Figures 6 and 9). Thus, oocytes from Esr2-null females had comparable DNA methylation levels to control oocytes, indicating that imprint DNA methylation acquisition was unaffected by Esr2 deficiency.

\section{METHYLATION ACQUISITION IN CX37-DEFICIENT OOCYTES}

Previous analyses have shown that oocytes in CX37-null ovaries arrest development before reaching meiotic competence, around the time the antrum begins to form ( 21 dpp; Simon et al., 1997; Carabatsos et al., 2000; Li et al., 2007). We collected and analyzed oocytes from Gja4-null $21 \mathrm{dpp}$ females, which ranged in diameter sizes from 35 to $55 \mu \mathrm{m}$ and from $28 \mathrm{dpp}$ females, which ranged in size from 50 to $60.5 \mu \mathrm{m}$. The maximum diameter obtained was $60.5 \mu \mathrm{m}$, consistent with previous studies (Simon et al., 1997; Carabatsos et al., 2000). To explore the relationship between gap

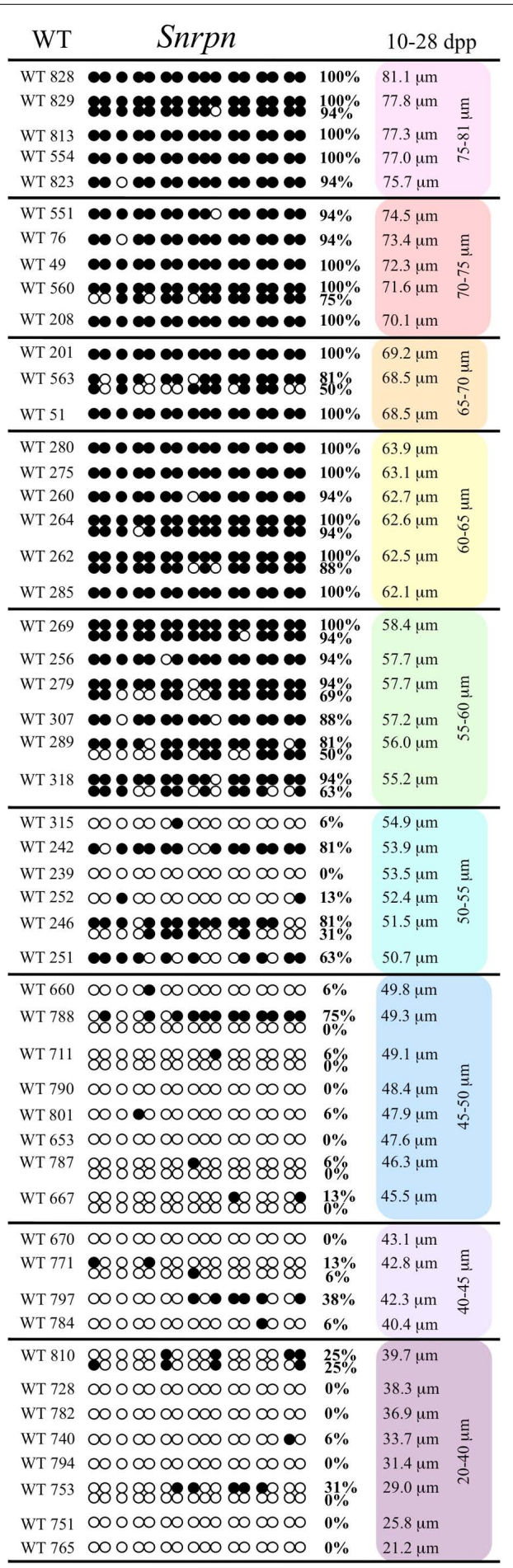

FIGURE 1 | Methylation analysis of the Snrpn ICR in individual oocytes derived from control C57BL/6 female mice. The Snrpn ICR region analyzed contains $16 \mathrm{CpGs}$. Black circles indicate methylated $\mathrm{CpGs}$ while white circles indicate unmethylated $\mathrm{CpGs}$. Each row represents an individual oocyte (designation indicated to the left). Methylation percentage and diameter for each oocyte is shown at the right. Oocytes are grouped into cohorts ranging from 20 to $80 \mu \mathrm{m}$ diameters in $5 \mu \mathrm{m}$ increments. Oocytes with one methylation pattern represent one of the two parental alleles detected. Oocytes with two methylation patterns represent detection of both parental alleles. 


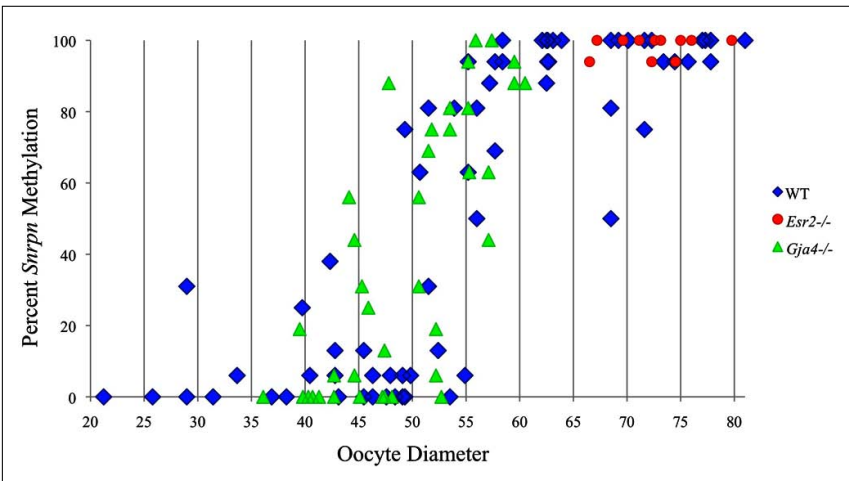

FIGURE 2 | Methylation percentage of each parental allele at the Snrpn ICR in relation to oocyte diameter $(\mu \mathrm{m})$. For oocytes with two parental alleles, each allele was graphed separately. Blue diamonds represent oocytes from control females, red circles represent oocytes from Esr2-/- females, and green triangles represent oocytes from $\mathrm{Gja}^{-{ }^{-1}}$ females.

junction loss and imprint acquisition, we analyzed the progression of DNA methylation establishment in developing oocytes from Gja4-deficient mice.

At the Snrpn ICR, mean methylation levels were $6.3 \%$ in $35-$ $40 \mu \mathrm{m}, 14.0 \%$ in $40-45 \mu \mathrm{m}, 17.4 \%$ in $45-50 \mu \mathrm{m}, 45.8 \%$ in $50-55 \mu \mathrm{m}, 80.8 \%$ in $55-60 \mu \mathrm{m}$, and $88.0 \%$ in $60-65 \mu \mathrm{m}$ oocytes (Figures 2 and 10). No significant difference was observed in methylation levels between Gja4-null and control oocytes. Analysis at the Peg3 DMR showed mean methylation levels of $2.7 \%$ for $35-40 \mu \mathrm{m}, 74.0 \%$ in $40-45 \mu \mathrm{m}, 28.0 \%$ for $45-50 \mu \mathrm{m}, 50.7 \%$ for $50-55 \mu \mathrm{m}$, and $55.3 \%$ for $55-60 \mu \mathrm{m}$ oocytes (Figures 4 and 11). No significant difference was observed in methylation levels between Gja4-null and control oocytes. For the Peg1 DMR, mean methylation levels were $1.8 \%$ in $35-40 \mu \mathrm{m}, 2.8 \%$ in $40-45 \mu \mathrm{m}$, $9.7 \%$ in $45-50 \mu \mathrm{m}, 14.3 \%$ in $50-55 \mu \mathrm{m}$, and $19.1 \%$ in $55-60 \mu \mathrm{m}$ oocytes (Figures 6 and 12). Statistical analysis of Peg1 showed a significant difference in methylation acquisition between control and Gja4-deficient oocytes $(P=0.0006)$. Because Gja4-null oocytes stop growing and are eventually lost from the follicles, it could not be determined whether this is a delay or a disruption in Peg1 DNA methylation acquisition.

\section{DISCUSSION}

Growth and maturation of oocytes within follicles requires bidirectional signaling and exchange of nutrients, metabolites, and second messengers through gap junctions between the oocyte and granulosa cells (Matzuk et al., 2002; Gilchrist et al., 2008; Su et al., 2009). Aberrant endocrine signaling and loss of gap junctional communication between the oocyte and granulosa cells leads to compromised folliculogenesis, oocyte maturation, and oocyte competency, consequently impairing fertility. Given that oocytespecific DNA methylation establishment at imprinted genes occurs during this growth phase, we determined whether compromised endocrine signaling and gap junctional communication would disrupt de novo methylation acquisition. Individual oocytes from Esr2- and Gja4-deficient mice were assessed for DNA methylation establishment at Snrpn, Peg3, and Pegl. We observed no aberrant or delayed acquisition of DNA methylation at Snrpn, Peg3, or

\begin{tabular}{|c|c|c|c|c|}
\hline WT & Peg3 & & $10-28 \mathrm{~d}$ & $d p p$ \\
\hline $\begin{array}{l}\text { WT } 557 \\
\text { WT } 116 \\
\text { WT } 112 \\
\text { WT } 558 \\
\text { WT } 172\end{array}$ & 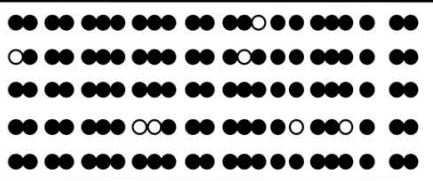 & \begin{tabular}{l|l|}
$96 \%$ \\
$91 \%$ \\
$100 \%$ \\
$83 \%$ \\
$100 \%$ \\
\end{tabular} & $\begin{array}{l}80.0 \mu \mathrm{m} \\
76.8 \mu \mathrm{m} \\
76.3 \mu \mathrm{m} \\
76.2 \mu \mathrm{m} \\
75.0 \mu \mathrm{m}\end{array}$ & $\begin{array}{l}E \\
\Xi \\
0 \\
\infty \\
1 \\
n\end{array}$ \\
\hline $\begin{array}{l}\text { WT } 186 \\
\text { WT } 561\end{array}$ & 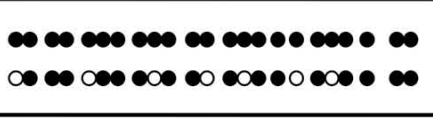 & $\begin{array}{l}100 \% \\
70 \%\end{array}$ & $\begin{array}{l}74.8 \mu \mathrm{m} \\
73.7 \mu \mathrm{m}\end{array}$ & $\begin{array}{l}\vdots \\
\frac{1}{2} \\
\frac{2}{2} \\
\frac{1}{2}\end{array}$ \\
\hline $\begin{array}{l}\text { WT } 241 \\
\text { WT } 582 \\
\text { WT } 820 \\
\text { WT } 564\end{array}$ & 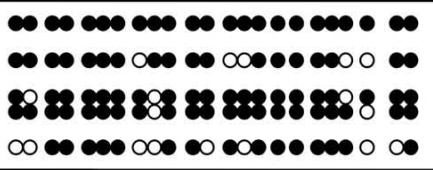 & $\begin{array}{l}100 \% \\
78 \% \\
87 \% \\
83 \% \\
65 \% \\
\end{array}$ & $\begin{array}{l}68.8 \mu \mathrm{m} \\
67.1 \mu \mathrm{m} \\
66.6 \mu \mathrm{m} \\
65.0 \mu \mathrm{m}\end{array}$ & $\begin{array}{l}\Xi \\
\vdots \\
\stackrel{1}{1} \\
\dot{b}\end{array}$ \\
\hline $\begin{array}{l}\text { WT } 587 \\
\text { WT } 569 \\
\text { WT } 568 \\
\text { WT } 224 \\
\text { WT } 735 \\
\text { WT } 577 \\
\text { WT } 652 \\
\text { WT } 598 \\
\text { WT } 575\end{array}$ & 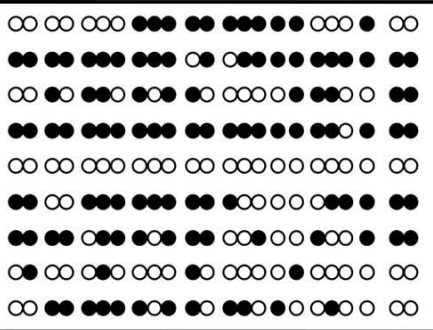 & \begin{tabular}{l|l|}
$28 \%$ \\
$87 \%$ \\
$48 \%$ \\
$96 \%$ \\
$0 \%$ \\
$71 \%$ \\
$65 \%$ \\
$18 \%$ \\
$52 \%$
\end{tabular} & $\begin{array}{l}64.6 \mu \mathrm{m} \\
64.5 \mu \mathrm{m} \\
63.1 \mu \mathrm{m} \\
62.8 \mu \mathrm{m} \\
62.5 \mu \mathrm{m} \\
62.2 \mu \mathrm{m} \\
61.9 \mu \mathrm{m} \\
61.1 \mu \mathrm{m} \\
60.3 \mu \mathrm{m}\end{array}$ & $\begin{array}{l}\Xi \\
\equiv \\
20 \\
1 \\
0\end{array}$ \\
\hline $\begin{array}{l}\text { WT } 576 \\
\text { WT } 326 \\
\text { WT } 331 \\
\text { WT } 595 \\
\text { WT } 581\end{array}$ & $\begin{array}{l}\boldsymbol{\omega} \\
\omega \\
\omega\end{array}$ & $\begin{array}{l}\mathbf{1 0 0} \% \\
\mathbf{7 0} \% \\
\mathbf{5 2} \% \\
\mathbf{5 2} \% \\
22 \% \\
\mathbf{7 4} \% \\
\mathbf{6 1} \% \\
22 \% \\
\mathbf{9 2} \% \\
13 \%\end{array}$ & $\begin{array}{l}56.9 \mu \mathrm{m} \\
56.9 \mu \mathrm{m} \\
56.8 \mu \mathrm{m} \\
56.6 \mu \mathrm{m} \\
55.8 \mu \mathrm{m}\end{array}$ & 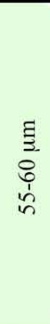 \\
\hline $\begin{array}{l}\text { WT } 573 \\
\text { WT } 583 \\
\text { WT } 594 \\
\text { WT } 228\end{array}$ & 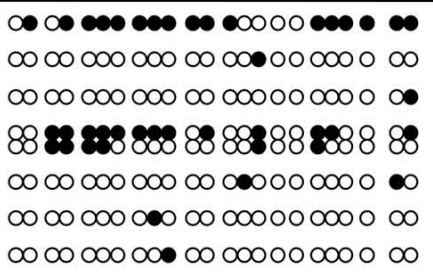 & $\begin{array}{l}75 \% \\
4 \% \\
4 \% \\
57 \% \\
26 \% \\
9 \% \\
4 \% \\
4 \%\end{array}$ & $\begin{array}{l}54.7 \mu \mathrm{m} \\
54.7 \mu \mathrm{m} \\
54.0 \mu \mathrm{m} \\
53.9 \mu \mathrm{m} \\
53.2 \mu \mathrm{m} \\
51.8 \mu \mathrm{m} \\
50.8 \mu \mathrm{m}\end{array}$ & $\begin{array}{l}E \\
5 \\
n \\
n \\
0 \\
n\end{array}$ \\
\hline $\begin{array}{l}\text { WT } 808 \\
\text { WT } 599 \\
\text { WT } 786 \\
\text { WT } 596 \\
\text { WT } 731\end{array}$ & 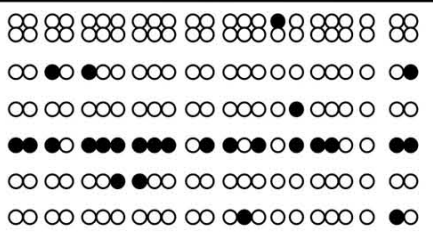 & \begin{tabular}{l|l|}
$4 \%$ \\
$0 \%$ \\
$13 \%$ \\
$4 \%$ \\
$74 \%$ \\
$9 \%$ \\
$9 \%$
\end{tabular} & $\begin{array}{l}48.9 \mu \mathrm{m} \\
47.9 \mu \mathrm{m} \\
47.5 \mu \mathrm{m} \\
46.1 \mu \mathrm{m} \\
45.8 \mu \mathrm{m} \\
45.6 \mu \mathrm{m}\end{array}$ & 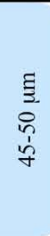 \\
\hline $\begin{array}{l}\text { WT } 773 \\
\text { WT } 767 \\
\text { WT } 755 \\
\text { WT } 756\end{array}$ & 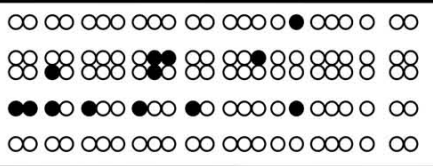 & \begin{tabular}{l|l|}
$4 \%$ \\
$13 \%$ \\
$9 \%$ \\
$30 \%$ \\
$0 \%$ \\
\end{tabular} & $\begin{array}{l}44.6 \mu \mathrm{m} \\
42.7 \mu \mathrm{m} \\
41.9 \mu \mathrm{m} \\
40.4 \mu \mathrm{m}\end{array}$ & $\begin{array}{c}\xi \\
\vdots \\
\vdots \\
\vdots \\
\vdots \\
\vdots \\
q\end{array}$ \\
\hline $\begin{array}{l}\text { WT } 806 \\
\text { WT } 743 \\
\text { WT } 798 \\
\text { WT } 789 \\
\text { WT } 760\end{array}$ & 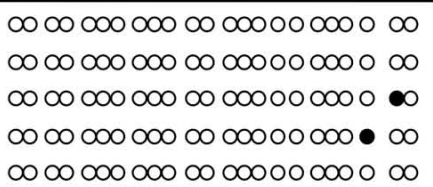 & $\begin{array}{l}0 \% \\
0 \% \\
4 \% \\
4 \% \\
0 \%\end{array}$ & $\begin{array}{l}38.8 \mu \mathrm{m} \\
36.4 \mu \mathrm{m} \\
34.2 \mu \mathrm{m} \\
30.0 \mu \mathrm{m} \\
23.0 \mu \mathrm{m}\end{array}$ & 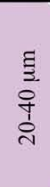 \\
\hline
\end{tabular}

FIGURE 3 | Methylation analysis of the Peg3 DMR in individual oocytes derived from control C57BL/6 females. The Peg3 DMR region analyzed contains $23 \mathrm{CpGs}$. Details are described in Figure 1 


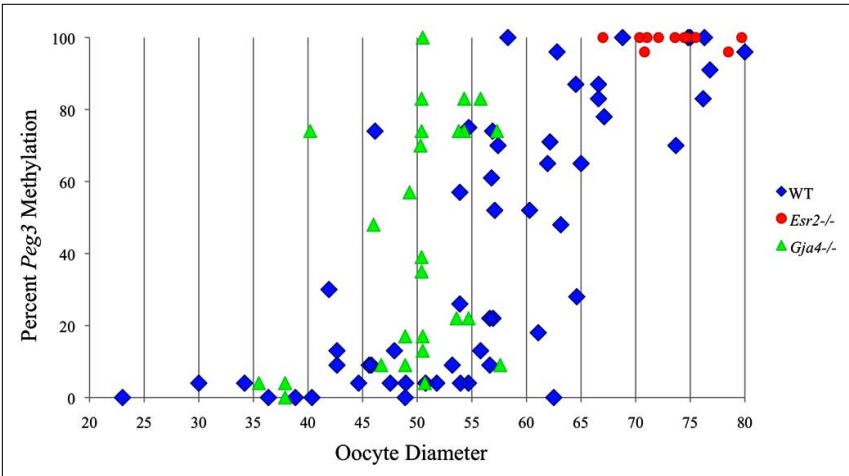

FIGURE 4 | Methylation percentage of each parental allele at the Peg3 DMR in relation to oocyte diameter $(\mu \mathrm{m})$. Oocytes from control females, Esr2 ${ }^{-1-}$ females and $\mathrm{Gja}^{-/-}$females are represented by blue diamonds, red circles and green triangles, respectively.

Peg1 in oocytes from Esr2-deficient females, and no perturbation in Snrpn or Peg3 de novo methylation in oocytes from Gja4-null females. However, Gja4 deficiency resulted in a loss or delay in methylation acquisition at Peg1. One possible explanation for this difference between the three loci analyzed is the late establishment of DNA methylation at the Peg1 gene. These results indicate that compromised fertility though impaired intercellular communication can lead to imprinting acquisition errors. Further studies are required to determine whether subfertility/infertility originating from impaired signaling and intercellular communication during oogenesis has an effect post-fertilization on imprint maintenance in the preimplantation embryo.

\section{GENE-SPECIFIC METHYLATION ACQUISITION ACCORDING TO OOCYTE SIZE}

Our study is the first to investigate imprint methylation acquisition of Snrpn, Peg3, and Peg1 in individual oocytes. We observed that each gene has its own size-dependent acquisition kinetics. Snrpn had the shortest acquisition interval with de novo methylation beginning at $\sim 50 \mu \mathrm{m}$ and near completion at $>60 \mu \mathrm{m}$. Peg3 had the earliest and longest acquisition interval. DNA methylation acquisition was initiated at $\sim 45 \mu \mathrm{m}$ and was nearly complete at $>65 \mu \mathrm{m}$. Peg1 had the latest acquisition of de novo methylation, beginning at $\sim 55 \mu \mathrm{m}$ and near completion by $>70 \mu \mathrm{m}$. Previous studies reported similar findings using pooled oocytes where methylation level increased with days postpartum, follicular stage or with oocyte diameter/size, and initiation of acquisition was gene-specific (Lucifero et al., 2004; Hiura et al., 2006; Sato et al., 2007; Song et al., 2009). Oocyte-specific de novo methylation was also found to occur differentially with the maternal allele acquiring methylation prior to the paternal allele for Snrpn, Zac1, and Peg1 (Lucifero et al., 2004; Hiura et al., 2006). Our data are consistent with this observation. Firstly, in oocytes for which two alleles were successfully amplified, one allele possessed higher and the other allele lower methylation levels, indicative of maternal and paternal contribution, respectively. For example, Snrpn WT563 oocyte had 81 and 50\% methylation (Figure 1). Secondly, for oocytes within each diameter range (see Peg 3 control oocytes between 60 and $65 \mu \mathrm{m}$; Figure 3), a subset of oocytes had high methylation

\begin{tabular}{|c|c|c|c|c|}
\hline WT & Pegl & & $10-28 \mathrm{~d}$ & $d p p$ \\
\hline $\begin{array}{l}\text { WT } 559 \\
\text { WT } 816 \\
\text { WT } 64 \\
\text { WT } 92 \\
\text { WT } 78\end{array}$ & 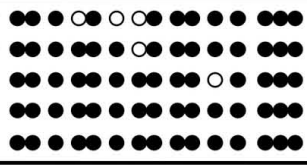 & \begin{tabular}{l|l}
$80 \%$ \\
$93 \%$ \\
$93 \%$ \\
$100 \%$ \\
$100 \%$ \\
\end{tabular} & $\begin{array}{l}80.0 \mu \mathrm{m} \\
79.9 \mu \mathrm{m} \\
78.9 \mu \mathrm{m} \\
76.1 \mu \mathrm{m} \\
76.0 \mu \mathrm{m} \\
\end{array}$ & 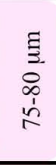 \\
\hline $\begin{array}{l}\text { WT } 837 \\
\text { WT } 849 \\
\text { WT } 70 \\
\text { WT } 274\end{array}$ & 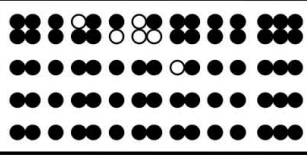 & $\begin{array}{l}87 \% \\
80 \% \\
93 \% \\
100 \% \\
100 \% \\
\end{array}$ & $\begin{array}{l}72.6 \mu \mathrm{m} \\
72.3 \mu \mathrm{m} \\
71.8 \mu \mathrm{m} \\
70.0 \mu \mathrm{m}\end{array}$ & $\frac{\Xi}{3}$ \\
\hline $\begin{array}{l}\text { WT } 93 \\
\text { WT } 265 \\
\text { WT } 864\end{array}$ & 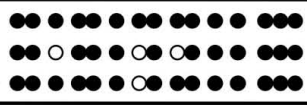 & $\begin{array}{l}100 \% \\
80 \% \\
93 \%\end{array}$ & $\begin{array}{l}69.3 \mu \mathrm{m} \\
68.3 \mu \mathrm{m} \\
66.7 \mu \mathrm{m}\end{array}$ & 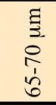 \\
\hline $\begin{array}{l}\text { WT } 200 \\
\text { WT } 219 \\
\text { WT } 244 \\
\text { WT } 333 \\
\text { WT } 278 \\
\text { WT } 245\end{array}$ & 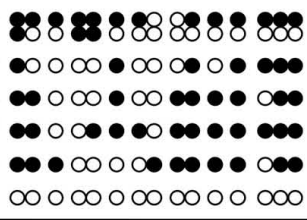 & $\begin{array}{l}87 \% \\
20 \% \\
47 \% \\
60 \% \\
80 \% \\
67 \% \\
0 \%\end{array}$ & $\begin{array}{l}64.7 \mu \mathrm{m} \\
64.0 \mu \mathrm{m} \\
61.3 \mu \mathrm{m} \\
60.8 \mu \mathrm{m} \\
60.6 \mu \mathrm{m} \\
60.5 \mu \mathrm{m}\end{array}$ & $\begin{array}{l}\vdots \\
\vdots \\
2 \\
\vdots \\
\vdots \\
0\end{array}$ \\
\hline $\begin{array}{l}\text { WT } 341 \\
\text { WT } 257 \\
\text { WT } 253 \\
\text { WT } 294 \\
\text { WT } 250 \\
\text { WT } 237 \\
\text { WT } 321\end{array}$ & 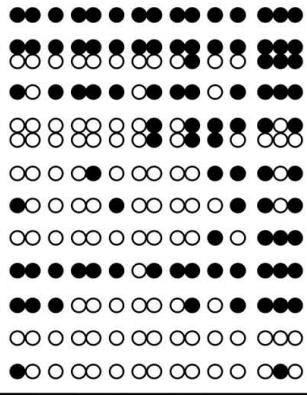 & $\begin{array}{l}100 \% \\
93 \% \\
27 \% \\
80 \% \\
40 \% \\
20 \% \\
33 \% \\
33 \% \\
27 \% \\
93 \% \\
13 \% \\
20 \% \\
13 \% \\
\end{array}$ & $\begin{array}{l}59.5 \mu \mathrm{m} \\
58.8 \mu \mathrm{m} \\
58.2 \mu \mathrm{m} \\
58.2 \mu \mathrm{m} \\
58.0 \mu \mathrm{m} \\
57.9 \mu \mathrm{m} \\
56.1 \mu \mathrm{m} \\
56.0 \mu \mathrm{m} \\
55.6 \mu \mathrm{m} \\
55.3 \mu \mathrm{m} \\
55.3 \mu \mathrm{m}\end{array}$ & $\begin{array}{l}\text { I } \\
8 \\
8 \\
\text { in } \\
\text { in }\end{array}$ \\
\hline $\begin{array}{l}\text { WT } 295 \\
\text { WT } 240 \\
\text { WT } 309 \\
\text { WT } 233 \\
\text { WT } 328\end{array}$ & 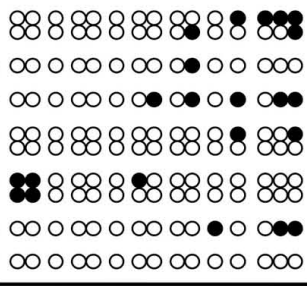 & $\begin{array}{l}27 \% \\
13 \% \\
20 \% \\
33 \% \\
13 \% \\
0 \% \\
20 \% \\
13 \% \\
20 \% \\
0 \% \\
\end{array}$ & $\begin{array}{l}54.5 \mu \mathrm{m} \\
54.2 \mu \mathrm{m} \\
54.1 \mu \mathrm{m} \\
53.3 \mu \mathrm{m}\end{array}$ & 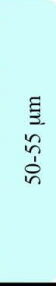 \\
\hline $\begin{array}{l}\text { WT } 803 \\
\text { WT } 793 \\
\text { WT } 325 \\
\text { WT } 662 \\
\text { WT } 804 \\
\text { WT } 768 \\
\text { WT } 785 \\
\text { WT } 799\end{array}$ & 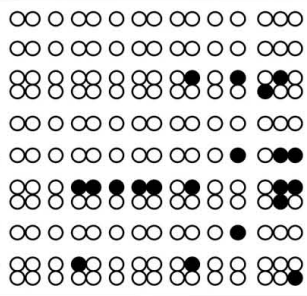 & \begin{tabular}{l|l}
$0 \%$ \\
$0 \%$ \\
$20 \%$ \\
$7 \%$ \\
$0 \%$ \\
$20 \%$ \\
$\mathbf{5 3} \%$ \\
$7 \%$ \\
$7 \%$ \\
$13 \%$ \\
$7 \%$
\end{tabular} & $\begin{array}{l}47.5 \mu \mathrm{m} \\
47.3 \mu \mathrm{m} \\
46.5 \mu \mathrm{m}\end{array}$ & 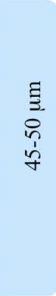 \\
\hline $\begin{array}{l}\text { WT } 778 \\
\text { WT } 750\end{array}$ & $\begin{array}{l}808888888888888 \\
\infty 0000000000\end{array}$ & $\begin{array}{l}7 \% \\
0 \% \\
7 \%\end{array}$ & $\begin{array}{l}44.1 \mu \mathrm{m} \\
40.8 \mu \mathrm{m} \\
\end{array}$ & 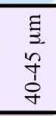 \\
\hline $\begin{array}{l}\text { WT } 795 \\
\text { WT } 807 \\
\text { WT } 763 \\
\text { WT } 796 \\
\text { WT } 775 \\
\text { WT } 741 \\
\text { WT } 742 \\
\text { WT } 776\end{array}$ & 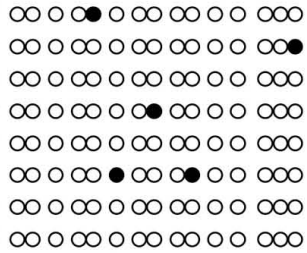 & \begin{tabular}{l|l|}
$7 \%$ \\
$7 \%$ \\
$0 \%$ \\
$7 \%$ \\
$0 \%$ \\
$13 \%$ \\
$0 \%$ \\
$0 \%$
\end{tabular} & $\begin{array}{l}39.9 \mathrm{um} \\
39.2 \mathrm{um} \\
35.9 \mathrm{um} \\
29.3 \mu \mathrm{m} \\
26.7 \mu \mathrm{m} \\
25.2 \mu \mathrm{m} \\
23.0 \mu \mathrm{m} \\
21.6 \mu \mathrm{m}\end{array}$ & $\begin{array}{l}\xi \\
\text { క. } \\
\text { +े } \\
\text { ते }\end{array}$ \\
\hline
\end{tabular}

FIGURE 5 | Methylation analysis of the Peg1 DMR in individual oocytes derived from the control C57BL/6 mice. The Peg1 DMR region analyzed contains $15 \mathrm{CpGs}$. Details are described in Figure 1. 


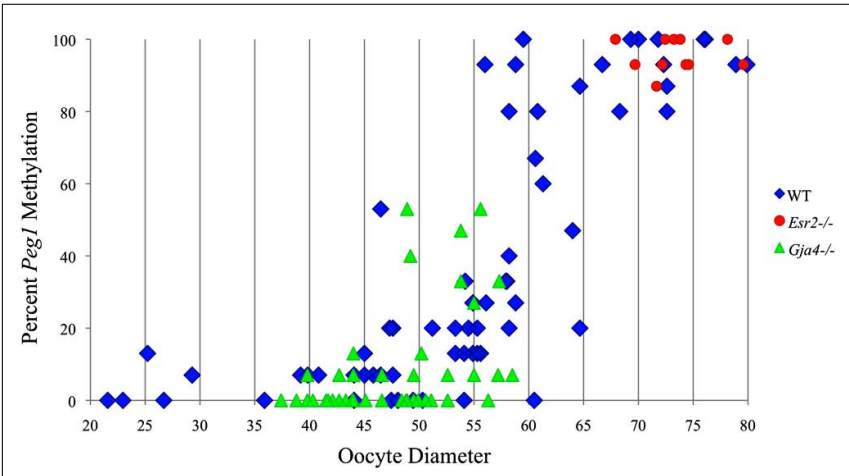

FIGURE 6 | Methylation percentage of each parental allele at the Peg1 DMR in relation to oocyte diameter $(\mu \mathbf{m})$. Oocytes from control females, Esr2 ${ }^{-1}$ - females and $\mathrm{Gja}^{-1-}$ females are represented by blue diamonds, red circles and green triangles, respectively.

\begin{tabular}{|c|c|c|c|c|}
\hline Esr 2-/ & Pegl & & \multicolumn{2}{|c|}{$28 \mathrm{dpp}$} \\
\hline $\begin{array}{l}\text { KO } 390 \\
\text { KO } 405\end{array}$ & 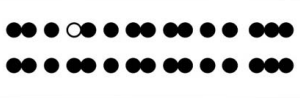 & $\begin{array}{l}93 \% \\
100 \%\end{array}$ & $\begin{array}{l}79.6 \mu \mathrm{m} \\
78.1 \mu \mathrm{m}\end{array}$ & $\begin{array}{l}E \\
0 \\
\infty \\
\infty \\
1 \\
1\end{array}$ \\
\hline $\begin{array}{l}\text { KO } 370 \\
\text { KO } 347 \\
\text { KO } 394 \\
\text { KO } 379 \\
\text { KO } 411 \\
\text { KO } 393 \\
\text { KO } 362\end{array}$ & 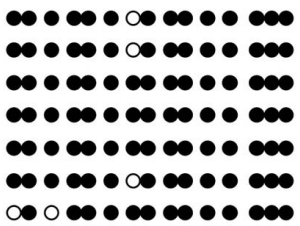 & $\begin{array}{l}93 \% \\
93 \% \\
100 \% \\
100 \% \\
100 \% \\
93 \% \\
87 \%\end{array}$ & $\begin{array}{l}74.6 \mu \mathrm{m} \\
74.3 \mu \mathrm{m} \\
73.8 \mu \mathrm{m} \\
73.2 \mu \mathrm{m} \\
72.4 \mu \mathrm{m} \\
72.2 \mu \mathrm{m} \\
71.7 \mu \mathrm{m}\end{array}$ & $\begin{array}{l}E \\
\vdots \\
\frac{1}{2} \\
\stackrel{1}{R}\end{array}$ \\
\hline $\begin{array}{l}\text { KO } 437 \\
\text { KO } 449\end{array}$ & 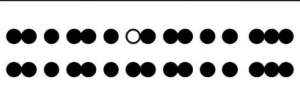 & $\begin{array}{l}93 \% \\
100 \%\end{array}$ & $\begin{array}{l}69.7 \mu \mathrm{m} \\
67.9 \mu \mathrm{m}\end{array}$ & 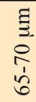 \\
\hline
\end{tabular}

FIGURE 9 | Methylation analysis of the Peg1 DMR individual oocytes derived from Esr2 ${ }^{-1-}$ female mice. Details are described in Figure 1

\begin{tabular}{|c|c|c|c|c|}
\hline $\operatorname{Esr}^{-1}$ & Snrpn & & \multicolumn{2}{|c|}{$28 \mathrm{dpp}$} \\
\hline KO 440 & $\bullet \bullet \bullet \bullet \bullet \omega \bullet \bullet$ & $100 \%$ & $79.8 \mu \mathrm{m}$ & $\Xi$ \\
\hline KO 408 & 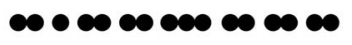 & $100 \%$ & $76.0 \mu \mathrm{m}$ & $\ddot{\infty}$ \\
\hline KO 401 & 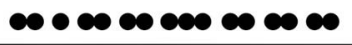 & $100 \%$ & $75.0 \mu \mathrm{m}$ & \\
\hline KO 446 & $\bullet \bullet \bullet \bullet \bullet \bullet \bullet \bullet \bullet$ & $94 \%$ & $74.5 \mu \mathrm{m}$ & \\
\hline KO 343 & $\bullet \bullet \bullet \bullet \bullet \bullet \bullet \bullet \bullet$ & $100 \%$ & $73.1 \mu \mathrm{m}$ & $\Xi$ \\
\hline KO 402 & $\bullet \bullet \bullet \bullet \bullet \bullet \bullet \bullet \bullet$ & $100 \%$ & $72.6 \mu \mathrm{m}$ & 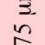 \\
\hline KO 354 & & $\begin{array}{l}94 \% \\
94 \%\end{array}$ & $72.3 \mu \mathrm{m}$ & 官 \\
\hline KO 400 & 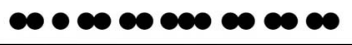 & $100 \%$ & $71.1 \mu \mathrm{m}$ & \\
\hline KO 344 & $\bullet \bullet \bullet \bullet \bullet \bullet \bullet \bullet \bullet \bullet$ & $100 \%$ & $69.6 \mu \mathrm{m}$ & Eี. \\
\hline KO 374 & $\bullet \bullet \bullet \bullet \bullet \bullet \bullet \bullet \bullet \bullet$ & $100 \%$ & $67.2 \mu \mathrm{m}$ & $?$ \\
\hline KO 412 & $\bullet \bullet \bullet \bullet \bullet \bullet \bullet \bullet$ & $94 \%$ & $66.5 \mu \mathrm{m}$ & 2 \\
\hline
\end{tabular}

FIGURE 7 | Methylation analysis of the Snrpn ICR in individual oocytes derived from Esr2 ${ }^{-/}$- females. Details are described in Figure 1.
FIGURE 8 | Methylation analysis of the Peg3 DMR in individual oocytes derived from Esr2 ${ }^{-/}$mice. Details are described in Figure 1.

\begin{tabular}{|c|c|c|c|c|}
\hline $\mathrm{Gja4}^{-}$ & Snrpn & & $21 / 28 \mathrm{c}$ & \\
\hline KO 468 & $\infty \bullet \bullet \bullet \infty \bullet \bullet \bullet \bullet \bullet$ & $88 \%$ & $60.5 \mu \mathrm{m}$ & 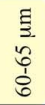 \\
\hline KO 452 & 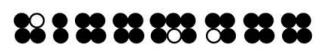 & $\begin{array}{l}94 \% \\
88 \%\end{array}$ & $59.5 \mu \mathrm{m}$ & \\
\hline KO 484 & 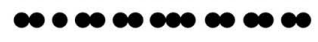 & $100 \%$ & $57.4 \mu \mathrm{m}$ & \\
\hline KO 501 & 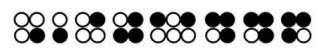 & $\begin{array}{l}63 \% \\
44 \%\end{array}$ & $57.1 \mu \mathrm{m}$ & $\begin{array}{l}5 \\
8 \\
8\end{array}$ \\
\hline KO 480 & 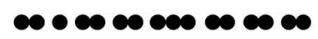 & $100 \%$ & $55.9 \mu \mathrm{m}$ & $\begin{array}{ll}0 \\
i n\end{array}$ \\
\hline KO 462 & $\bullet \bullet \propto \bullet \bullet \bullet \bullet \bullet \bullet \bullet$ & $63 \%$ & $55.3 \mu \mathrm{m}$ & \\
\hline $\mathrm{KO} 463$ & 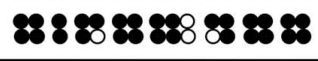 & $\begin{array}{l}94 \% \\
81 \%\end{array}$ & $55.2 \mu \mathrm{m}$ & \\
\hline KO 21 & 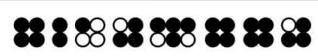 & $\begin{array}{l}81 \% \\
75 \%\end{array}$ & $53.5 \mu \mathrm{m}$ & \\
\hline KO 19 & $\infty \circ \infty \infty \infty \infty \infty \propto \infty \infty \infty \infty$ & $0 \%$ & $52.7 \mu \mathrm{m}$ & \\
\hline KO 29 & 8888880880888888 & $\begin{array}{l}19 \% \\
6 \%\end{array}$ & $52.2 \mu \mathrm{m}$ & 焉 \\
\hline KO 25 & $\bullet \bullet \bullet \bullet \bullet \propto \infty \circ \bullet \bullet \bullet \bullet$ & $75 \%$ & $51.8 \mu \mathrm{m}$ & $\hat{\imath}$ \\
\hline KO 31 & $\bullet \bullet \bullet \infty \infty \infty \bullet \infty \bullet \bullet \bullet$ & $69 \%$ & $51.5 \mu \mathrm{m}$ & \\
\hline KO 60 & $8888888880 \bullet 8888$ & $\begin{array}{l}56 \% \\
31 \%\end{array}$ & $50.6 \mu \mathrm{m}$ & \\
\hline KO 118 & $\infty \circ \infty \infty \infty \infty) \infty \infty \infty$ & $0 \%$ & $48.1 \mu \mathrm{m}$ & \\
\hline KO 129 & $\bullet \bullet \bullet \bullet \bullet \bullet \bullet \bullet \bullet \bullet \bullet \bullet$ & $88 \%$ & $47.8 \mu \mathrm{m}$ & \\
\hline KO 97 & 8888880888888888 & $13 \%$ & $47.4 \mu \mathrm{m}$ & \\
\hline KO 102 & $\infty \circ \infty \infty \infty \infty \infty \infty \infty \infty$ & $0 \%$ & $47.2 \mu \mathrm{m}$ & 3. \\
\hline KO 86 & $\infty \circ \infty \infty \bullet \infty \infty \infty \infty$ & $25 \%$ & $45.9 \mu \mathrm{m}$ & 年 \\
\hline KO 79 & $\infty \bullet \infty \infty \infty) \infty \bullet \bullet$ & $31 \%$ & $45.3 \mu \mathrm{m}$ & \\
\hline KO 107 & $\infty \circ \infty \infty \infty \infty \infty \infty \infty \infty)$ & $0 \%$ & $45.1 \mu \mathrm{m}$ & \\
\hline KO 27 & $\infty \circ \infty \infty \infty \infty \infty \infty \infty \infty$ & $0 \%$ & $45.1 \mu \mathrm{m}$ & \\
\hline KO 125 & 8888880888888880 & $\begin{array}{l}44 \% \\
6 \%\end{array}$ & $44.6 \mu \mathrm{m}$ & \\
\hline KO 84 & $\infty \bullet \infty \bullet \infty \infty) \bullet \bullet \bullet \bullet$ & $56 \%$ & $44.1 \mu \mathrm{m}$ & \\
\hline KO 80 & 8088888888888888 & 6\% & $42.7 \mu \mathrm{m}$ & $\frac{\xi}{5}$ \\
\hline $\mathrm{KO} 2$ & $\infty \circ \infty \infty \infty \infty \infty \infty \infty \infty$ & $0 \%$ & $41.3 \mu \mathrm{m}$ & o \\
\hline KO 141 & $\infty, \infty \infty \infty \infty \infty \infty \infty \infty$ & $0 \%$ & $40.7 \mu \mathrm{m}$ & \\
\hline KO 64 & $\infty \circ \infty \infty \infty \infty \infty \infty \infty \infty$ & $0 \%$ & $40.3 \mu \mathrm{m}$ & \\
\hline KO 83 & $\infty \circ \infty \infty \infty \infty \infty \infty \infty \infty)$ & $0 \%$ & $39.8 \mu \mathrm{m}$ & 国 \\
\hline KO 61 & $\infty \circ \infty \infty \bullet \infty \infty \infty$ & $19 \%$ & $39.5 \mu \mathrm{m}$ & 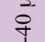 \\
\hline KO 110 & $\infty \circ \infty \infty \infty \infty \infty \infty \infty \infty$ & $0 \%$ & $36.1 \mu \mathrm{m}$ & $m$ \\
\hline
\end{tabular}

FIGURE 10 | Methylation analysis of the Snrpn ICR in individual oocytes derived from $\mathrm{Gja}^{-/-}$mice. Details are described in Figure 1. 


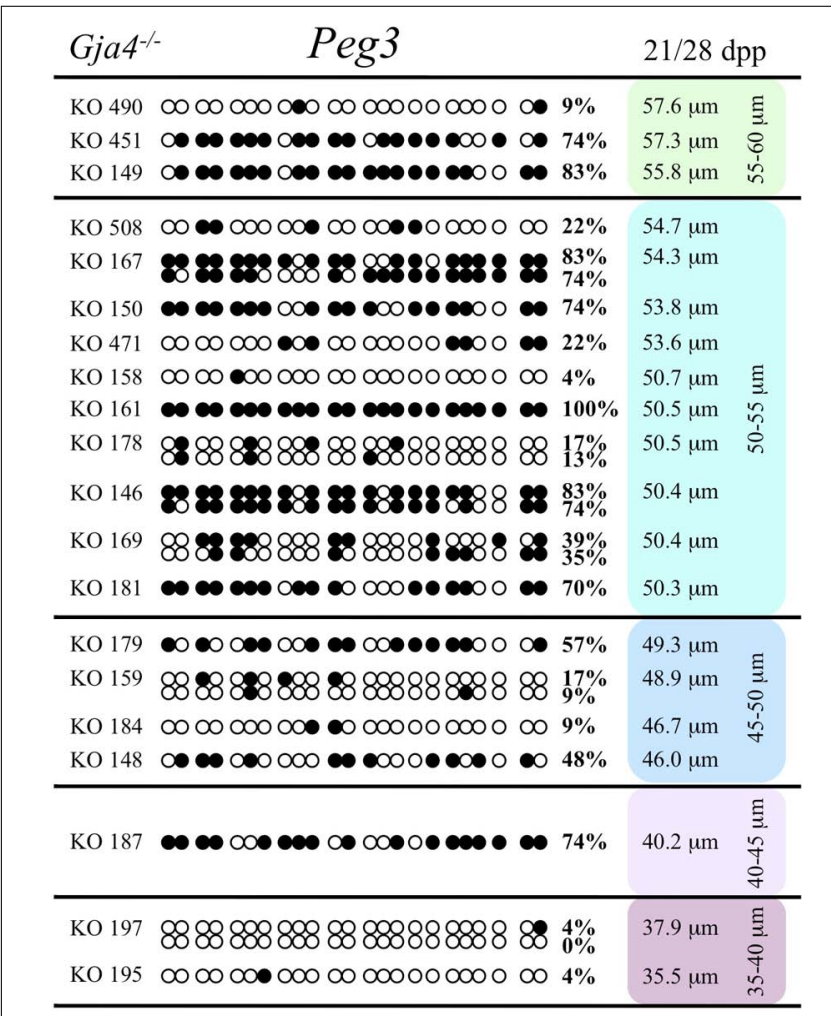

FIGURE 11 | Methylation analysis of the Peg3 DMR individual GV oocytes derived from $\mathrm{Gja4}^{-/-}$female mice. Details are described in Figure 1.

percentages $(68,71,87$, and $96 \%$, indicative of the maternal allele) while others had low methylation percentages $(18,28,48,52 \%$, indicative of the paternal allele). Finally, scatter plots show two distinct cohorts within the same range of diameter measurements. For example, Peg1 control oocytes between 55 and $65 \mu \mathrm{m}$ grouped into $0-40 \%$ methylation and $75-100 \%$ methylation (Figure 6).

\section{COMPROMISED FERTILITY LEADS TO LOSS OR DELAYED Peg1 METHYLATION ACOUISITION}

While Gja4-deficient oocytes ceased development and did not achieve mature size, our analyses indicated that they were not compromised in their ability to catalyze DNA methylation as de novo DNA methylation was initiated for the Snrpn and Peg3 imprinted genes. The failure to initiate Peg1 methylation acquisition may simply be due to the fact that oocytes lacking CX37 never reach the size necessary for de novo methylation to commence at late-acquiring loci. However, control oocytes of comparable size (55-60 $\mu \mathrm{m})$ displayed initiation of de novo Peg1 methylation. This suggests that Peg1 methylation acquisition was lost or delayed in mutant oocytes. Alternatively, CX37-null oocytes may have reduced stores of methyl donors or other metabolites required for DNA methylation that would normally be transported from granulosa cells to the oocyte via gap junctions. If this is the case, then there must have been sufficient availability of methyl donors in mutant oocytes for Snrpn and Peg3 de novo methylation, but oocytes lacking junctional coupling with the granulosa cells may have exhausted their methyl

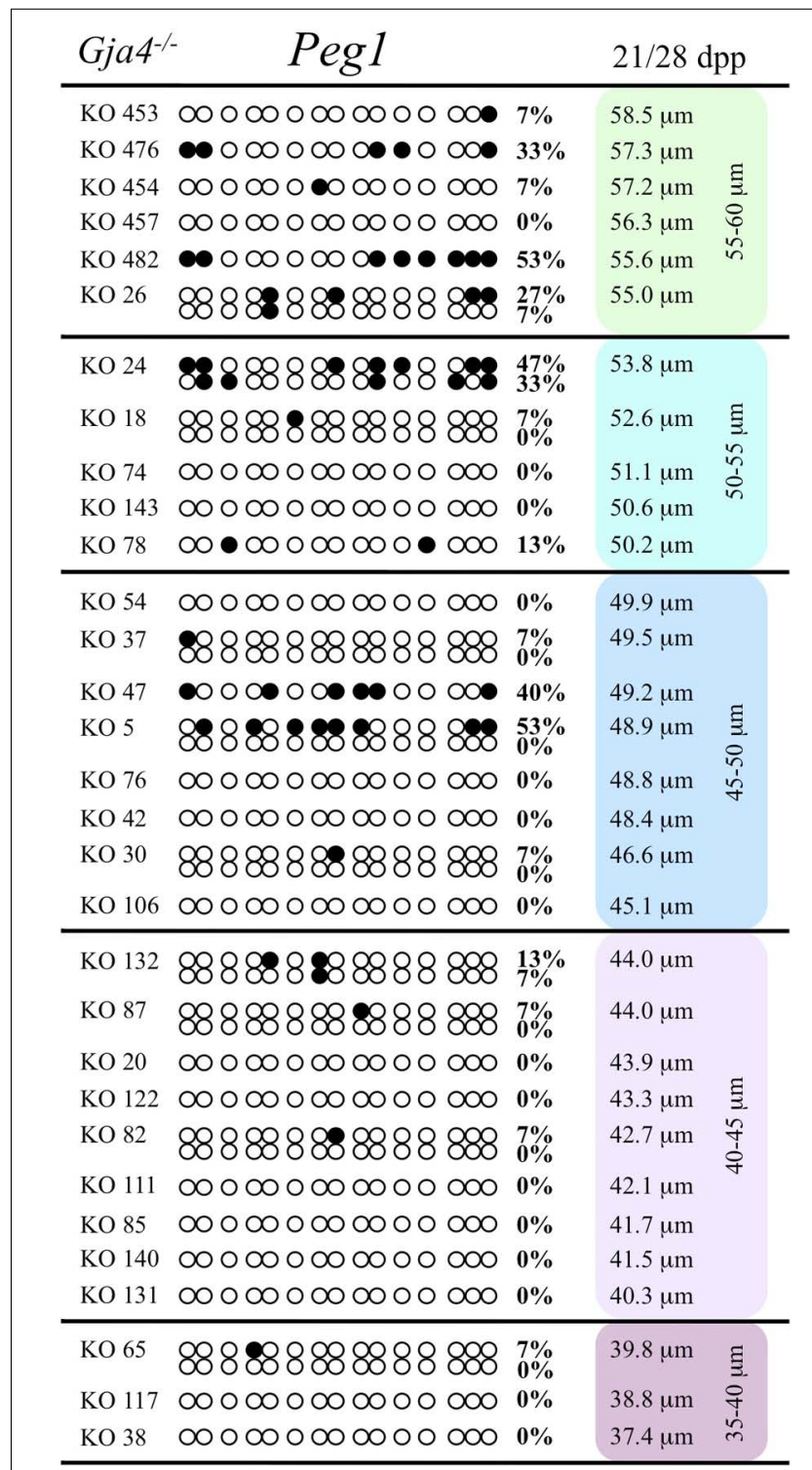

FIGURE 12 | Methylation analysis of the Peg1 DMR individual GV oocytes derived from $\mathrm{Gja4}^{-/-}$females. Details are described in Figure 1.

donors during oocyte growth, preventing de novo methylation at late-acquiring genes like Pegl. To investigate the requirement for methyl donors during follicle development, Anckaert et al. (2010) cultured preantral follicles in medium with low methyl donors. While this led to impaired antrum development and polar body formation, it did not impede the acquisition of DNA methylation at the Snrpn ICR and the Peg3 DMR. However, a reduced level of DNA methylation was found at the Peg1 DMR. This provides support for the argument that gap junctional communication provides important metabolites for DNA methylation acquisition. To better understand the mechanism leading to loss or delayed methylation acquisition, further studies are required to assess the level of methyl donors, amount of $S$-adenosylmethionine, and ability to carry out global and gene-specific methylation in 55-60 $\mu \mathrm{m}$ 
CX37-null or CX37-depleted oocytes. Furthermore, methylation studies should be carried out using $\mathrm{F}_{1}$ females. For Peg1 CX37 oocytes between 45 and $60 \mu \mathrm{m}$, oocytes possessed $0-53 \%$ methylation. DNA methylation acquisition was likely initiated on the maternal Peg1 allele in some oocytes, while other oocytes lacked methylation on both parental alleles. Thus, loss or delayed Peg1 methylation acquisition may preferentially lead to a failure of the paternal allele to become methylated. Further studies are required to investigate this potential grandpaternal effect.

Peg1 may also be more susceptible to perturbation by assisted reproductive technologies. Loss of Peg1/PEG1 methylation was observed in mouse oocytes following in vitro maturation (Kerjean et al., 2003), and human oocytes following ovarian stimulation (Sato etal., 2007). Further studies are required to determine whether the susceptibility of $\operatorname{Peg} 1$ to perturbation relates to its late acquisition of methylation or whether a different epigenetic regulatory mechanism(s) operates at this gene. Superovulation also caused imprinting errors in the mouse preimplantation embryo (Market-Velker et al., 2010), although imprinted methylation acquisition was not perturbed in mouse oocytes by exogenous hormone treatment (Anckaert et al., 2009; Denomme et al., 2011). We hypothesized that superovulation disrupts maternaleffect gene products required for imprint maintenance during embryo development. Thus, impaired fertility may not only disrupt Peg1 methylation acquisition but may also lead to inadequate stores of maternal products, including those from granulosa cells, that may disrupt imprint maintenance at Peg1 as well as at Snrpn and Peg3 during preimplantation development. Extending studies to preimplantation embryos generated from fertilized ER $\beta$-deficient and CX37-depleted oocytes will be required to determine their effects on imprint maintenance. In addition, further studies are required to determine whether assisted reproductive technologies, such as in vitro oocyte maturation and superovulation, lead to aberrant endocrine and paracrine signaling as well as granulosa cell-oocyte gap junctional communication.

It is important to understand granulosa cell-oocyte communication as technological advances move forward. Procedures such as slow-freezing cryopreservation and ultra-fast vitrification

\section{REFERENCES}

Anckaert, E., Adriaenssens, T., Romero, S., Dremier, S., and Smitz, J. (2009). Unaltered imprinting establishment of key imprinted genes in mouse oocytes after in vitro follicle culture under variable folliclestimulating hormone exposure. Int. J. Dev. Biol. 53, 541-548.

Anckaert, E., Romero, S., Adriaenssens, T., and Smitz, J. (2010). Effects of low methyl donor levels in culture medium during mouse follicle culture on oocyte imprinting establishment. Biol. Reprod. 83, 377-386.

Azzi, S., Rossignol, S., Steunou, V., Sas, T., Thibaud, N., Danton, F., Le Jule, M., Heinrichs, C., Cabrol, S., Gicquel, C., Le Bouc, Y., and Netchine, I. (2009).

of oocyte-enclosed follicles, which employ cryoprotectants and very low temperatures, may permanently or temporally disrupt actin- or tubulin-rich projections that extend from granulosa cells through the zona pellucida to the oocyte (Kidder and Mhawi, 2002). Slow-freezing of mouse, rhesus monkey, and human preantral follicles disrupted projections and uncoupled the oocyte and granulosa cells (Barrett and Albertini, 2010). Temporal disruption of oocyte-granulosa cell contacts was also observed following vitrification (Trapphoff et al., 2010). Thus, transfer of molecules between the two compartments may be temporarily disturbed. While low levels of imprinting errors were detected in a subset of oocyte pools following vitrification (Trapphoff et al., 2010), further studies are required to determine whether disruption of oocyte-granulosa coupling leads to errors in imprint acquisition and/or maintenance.

Continued studies in animal models and in humans are required to understand the molecular mechanisms regulating genomic imprinting acquisition and maintenance as well as how impaired fertility and assisted reproductive technologies induce epigenetic changes and disease.

\section{ACKNOWLEDGMENTS}

The authors thank Dr. Greg Gloor for statistical advice, Dr. Chris Pin for control C57BL/6 female mice, Lucimar Teodoro, Linsay Drysdale, and Adrian Buensuceso for technical assistance, Kevin Barr for management of the CX37 deleted mouse colony, and staff at the University of Western Ontario and the London Health Science Centre for animal care. This work was supported by the University of Western Ontario, the Department of Obstetrics and Gynaecology to Mellissa R. W. Mann; and grants from the Ministry of Research and Innovation, Early Researcher Award to Mellissa R. W. Mann (ER06-02-188) and the Canadian Institutes of Health Research to Bonnie J. Deroo (MOP 93658) and to Gerald M. Kidder (MOP14150). Michelle M. Denomme was supported by a CIHR Training Program in Reproduction, Early Development and the Impact on Health (REDIH) Graduate Scholarship, Carlee R. White by an Ontario Graduate Scholarship, and William A. MacDonald by a Children's Health Research Institute Postdoctoral Fellowship.

Cerrato, F., Russo, S., Ferraiuolo, S. Rinaldi, M. M., Fischetto, R., Lalatta, F., Giordano, L., Ferrari, P., Cubellis, M. V., Larizza, L., Temple, I. K., Mannens, M. M., Mackay, D. J. and Riccio, A. (2009). Hypomethylation at multiple maternally methylated imprinted regions including PLAGLl and GNAS loci in BeckwithWiedemann syndrome. Eur. J. Hum. Genet. 17, 611-619.

Carabatsos, M. J., Sellitto, C., Goodenough, D. A., and Albertini, D. F. (2000). Oocyte-granulosa cell heterologous gap junctions are required for the coordination of nuclear and cytoplasmic meiotic competence. Dev. Biol. 226, 167-179.

Chang, A. S., Moley, K. H., Wangler, M., Feinberg, A. P., and
DeBaun, M. R. (2005). Association between Beckwith-Wiedemann syndrome and assisted reproductive technology: a case series of 19 patients. Fertil. Steril. 83, 349-354.

Couse, J. F., Curtis Hewitt, S., and Korach, K. S. (2000). Receptor null mice reveal contrasting roles for estrogen receptor alpha and beta in reproductive tissues. J. Steroid Biochem. Mol. Biol. 74, 287-296.

Couse, J. F., Yates, M. M., Deroo, B. J., and Korach, K. S. (2005). Estrogen receptor-beta is critical to granulosa cell differentiation and the ovulatory response to gonadotropins. Endocrinology 146, 3247-3262.

Couse, J. F., Yates, M. M., Walker, V. R., and Korach, K. S. (2003). 
Characterization of the hypothalamic-pituitary-gonadal axis in estrogen receptor (ER) Nul mice reveals hypergonadism and endocrine sex reversal in females lacking ERalpha but not ERbeta. Mol. Endocrinol. 17, 1039-1053.

Cox, G. F., Burger, J., Lip, V., Mau, U. A., Sperling, K., Wu, B. L., and Horsthemke, B. (2002). Intracytoplasmic sperm injection may increase the risk of imprinting defects. Am. J. Hum. Genet. 71, 162-164.

Davis, T. L., Trasler, J. M., Moss, S. B., Yang, G. J., and Bartolomei, M. S. (1999). Acquisition of the H19 methylation imprint occurs differentially on the parental alleles during spermatogenesis. Genomics 58, 18-28.

Davis, T. L., Yang, G. J., McCarrey, J. R., and Bartolomei, M. S. (2000). The H19 methylation imprint is erased and re-established differentially on the parental alleles during male germ cell development. Hum. Mol. Genet. 9, 2885-2894.

DeBaun, M. R., Niemitz, E. L., and Feinberg, A. P. (2003). Association of in vitro fertilization with BeckwithWiedemann syndrome and epigenetic alterations of LIT1 and H19. Am. J. Hum. Genet. 72, 156-160.

Denomme, M. M., Zhang, L., and Mann, M. R. (2011). Embryonic imprinting perturbations do not originate from superovulationinduced defects in DNA methylation acquisition. Fertil. Steril. 96, 734738.e732.

Deroo, B. J., Rodriguez, K. F., Couse, J. F., Hamilton, K. J., Collins, J. B., Grissom, S. F., and Korach, K. S. (2009). Estrogen receptor beta is required for optimal cAMP production in mouse granulosa cells. Mol. Endocrinol. 23, 955-965.

Doornbos, M. E., Maas, S. M., Mcdonnell, J., Vermeiden, J. P., and Hennekam, R. C. (2007). Infertility, assisted reproduction technologies and imprinting disturbances: a Dutch study. Hum. Reprod. 22, 2476-2480.

Drummond, A. E., and Fuller, P. J. (2011). Activin and inhibin, estrogens and NFKB, play roles in ovarian tumourigenesis is there crosstalk? Mol. Cell. Endocrinol. 359, 85-91.

Dupont, S., Krust, A., Gansmuller, A., Dierich, A., Chambon, P., and Mark, M. (2000). Effect of single and compound knockouts of estrogen receptors alpha (ERalpha) and beta (ERbeta) on mouse reproductive phenotypes. Development 127 , 4277-4291.

Eggermann, T. (2010). Russell-Silver syndrome. Am. J. Med. Genet.
C Semin. Med. Genet. 154C, 355-364.

Emmen, J. M., Couse, J. F., Elmore, S. A., Yates, M. M., Kissling, G. E., and Korach, K. S. (2005). In vitro growth and ovulation of follicles from ovaries of estrogen receptor (ER) $\{$ alpha $\}$ and ER $\{$ beta $\}$ null mice indicate a role for ER\{beta\} in follicular maturation. Endocrinology 146 , 2817-2826.

Gicquel, C., Gaston, V., Mandelbaum, J., Siffroi, J. P., Flahault, A., and Le Bouc, Y. (2003). In vitro fertilization may increase the risk of BeckwithWiedemann syndrome related to the abnormal imprinting of the KCN1OT gene. Am. J. Hum. Genet. 72, 13381341.

Gilchrist, R. B., Lane, M., and Thompson, J. G. (2008). Oocyte-secreted factors: regulators of cumulus cell function and oocyte quality. Hum. Reprod. Update 14, 159-177.

Halliday, J., Oke, K., Breheny, S., Algar, E., and Amor, D. J. (2004). BeckwithWiedemann syndrome and IVF: a case-control study. Am. J. Hum. Genet. 75, 526-528.

Harris, A. L. (2001). Emerging issues of connexin channels: biophysics fills the gap. Q. Rev. Biophys. 34, 325-472.

Hiura, H., Obata, Y., Komiyama, J., Shirai, M., and Kono, T. (2006). Oocyte growth-dependent progression of maternal imprinting in mice. Genes Cells 11, 353-361.

Inzunza, J., Morani, A., Cheng, G., Warner, M., Hreinsson, J., Gustafsson, J. A., and Hovatta, O. (2007). Ovarian wedge resection restores fertility in estrogen receptor beta knockout (ERbeta-/-) mice. Proc. Natl. Acad. Sci. U.S.A. 104, 600-605.

Kafri, T., Ariel, M., Brandeis, M., Shemer, R., Urven, L., Mccarrey, J., Cedar H., and Razin, A. (1992). Developmental pattern of gene-specific DNA methylation in the mouse embryo and germ line. Genes Dev. 6, 705-714.

Kerjean, A., Couvert, P., Heams, T., Chalas, C., Poirier, K., Chelly, J., Jouannet, P., Paldi, A., and Poirot, C. (2003). In vitro follicular growth affects oocyte imprinting establishment in mice. Eur. J. Hum. Genet. 11, 493-496.

Kidder, G. M., and Mhawi, A. A (2002). Gap junctions and ovarian folliculogenesis. Reproduction 123, 613-620.

Kidder, G. M., and Vanderhyden, B. C. (2010). Bidirectional communication between oocytes and follicle cells: ensuring oocyte developmental competence. Can. J. Physiol. Pharmacol. 88, 399-413.

Krege, J. H., Hodgin, J. B., Couse, J. F., Enmark, E., Warner, M., Mahler, J. F. Sar, M., Korach, K. S., Gustafsson, J. A., and Smithies, O. (1998). Generation and reproductive phenotypes of mice lacking estrogen receptor beta. Proc. Natl. Acad. Sci. U.S.A. 95, 15677-15682.

Lennerz, J. K., Timmerman, R. J., Grange, D. K., DeBaun, M. R., Feinberg, A. P., and Zehnbauer, B. A. (2010). Addition of H19 'loss of methylation testing' for Beckwith-Wiedemann syndrome (BWS) increases the diagnostic yield. J. Mol. Diagn. 12, 576-588.

Li, T. Y., Colley, D., Barr, K. J., Yee, S. P., and Kidder, G. M. (2007). Rescue of oogenesis in Cx37-null mutant mice by oocyte-specific replacement with Cx43. J. Cell Sci. 120, 4117-4125.

Li, Y., and Sasaki, H. (2011). Genomic imprinting in mammals: its life cycle, molecular mechanisms and reprogramming. Cell Res. 21, 466-473.

Lim, D., Bowdin, S. C., Tee, L., Kirby, G. A., Blair, E., Fryer, A. Lam, W., Oley, C., Cole, T., Brueton, L. A., Reik, W., Macdonald, F., and Maher, E. R. (2009). Clinical and molecular genetic features of Beckwith-Wiedemann syndrome associated with assisted reproductive technologies. Hum. Reprod. 24, 741-747.

Lucifero, D., Mann, M. R., Bartolomei, M. S., and Trasler, J. M. (2004) Gene-specific timing and epigenetic memory in oocyte imprinting. Hum. Mol. Genet. 13, 839-849.

Ludwig, M., Katalinic, A., Gross, S., Sutcliffe, A., Varon, R., and Horsthemke, B. (2005). Increased prevalence of imprinting defects in patients with Angelman syndrome born to subfertile couples. J. Med. Genet. 42, 289-291.

Mabb, A. M., Judson, M. C., Zylka, M. J., and Philpot, B. D. (2011). Angelman syndrome: insights into genomic imprinting and neurodevelopmental phenotypes. Trends $\mathrm{Neu}$ rosci. 34, 293-303.

Maher, E. R., Brueton, L. A., Bowdin, S. C., Luharia, A., Cooper, W., Cole, T. R., Macdonald, F., Sampson, J. R., Barratt, C. L., Reik, W., and Hawkins, M. M. (2003). Beckwith-Wiedemann syndrome and assisted reproduction technology (ART). J. Med. Genet. 40, 62-64.

Market-Velker, B. A., Zhang, L., Magri, L. S., Bonvissuto, A. C., and Mann, M. R. (2010). Dual effects of superovulation: loss of maternal and paternal imprinted methylation in a dose-dependent manner. Hum. Mol. Genet. 19, 36-51.

Matzuk, M. M., Burns, K. H., Viveiros, M. M., and Eppig, J. J. (2002). Intercellular communication in the mammalian ovary: oocytes carry the conversation. Science 296, 2178-2180.

Orstavik, K. H., Eiklid, K., Van Der Hagen, C. B., Spetalen, S., Kierulf, K., Skjeldal, O., and Buiting, K. (2003). Another case of imprinting defect in a girl with Angelman syndrome who was conceived by intracytoplasmic semen injection. Am. J. Hum. Genet. 72, 218-219.

Rossignol, S., Steunou, V., Chalas, C., Kerjean, A., Rigolet, M., ViegasPequignot, E., Jouannet, P., Le Bouc, Y., and Gicquel, C. (2006). The epigenetic imprinting defect of patients with Beckwith-Wiedemann syndrome born after assisted reproductive technology is not restricted to the $11 \mathrm{p} 15$ region. J. Med. Genet. 43, 902-907.

Sato, A., Otsu, E., Negishi, H., Utsunomiya, T., and Arima, T. (2007). Aberrant DNA methylation of imprinted loci in superovulated oocytes. Hum. Reprod. 22, 26-35.

Simon, A. M., Goodenough, D. A., Li, E., and Paul, D. L. (1997). Female infertility in mice lacking connexin 37. Nature 385, 525-529.

Song, Z., Min, L., Pan, Q., Shi, Q., and Shen, W. (2009). Maternal imprinting during mouse oocyte growth in vivo and in vitro. Biochem. Biophys. Res. Commun. 387, 800-805.

Su, Y. Q., Sugiura, K., and Eppig, J. J. (2009). Mouse oocyte control of granulosa cell development and function: paracrine regulation of cumulus cell metabolism. Semin. Reprod. Med. 27, 32-42.

Trapphoff, T., El Hajj, N., Zechner, U., Haaf, T., and Eichenlaub-Ritter, U. (2010). DNA integrity, growth pattern, spindle formation, chromosomal constitution and imprinting patterns of mouse oocytes from vitrified pre-antral follicles. Hum. Reprod. 25, 3025-3042.

Turner, C. L., Mackay, D. M., Callaway, J. L., Docherty, L. E., Poole, R. L., Bullman, H., Lever, M., Castle, B. M., Kivuva, E. C., Turnpenny, P. D., Mehta, S. G., Mansour, S., Wakeling, E. L., Mathew, V., Madden, J., Davies, J. H., and Temple, I. K. (2010). Methylation analysis of 79 patients with growth restriction reveals novel patterns of methylation change at imprinted loci. Eur. J. Hum. Genet. 18, 648-655. 
Ueda, T., Abe, K., Miura, A., Yuzuriha, M., Zubair, M., Noguchi, M., Niwa, K., Kawase, Y., Kono, T., Matsuda, Y., Fujimoto, H., Shibata, H., Hayashizaki, Y., and Sasaki, H. (2000). The paternal methylation imprint of the mouse $\mathrm{H} 19$ locus is acquired in the gonocyte stage during foetal testis development. Genes Cells 5, 649-659.

Verona, R. I., Mann, M. R., and Bartolomei, M. S. (2003). Genomic imprinting: intricacies of epigenetic regulation in clusters. Annu. Rev. Cell Dev. Biol. 19, 237-259.

Weksberg, R., Shuman, C., and Beckwith, J. B. (2010). BeckwithWiedemann syndrome. Eur. J. Hum. Genet. 18, 8-14.

Conflict of Interest Statement: The authors declare that the research was conducted in the absence of any commercial or financial relationships that could be construed as a potential conflict of interest.

Received: 31 March 2012; accepted: 22 June 2012; published online: 11 July 2012. Citation: Denomme MM, White CR Gillio-Meina C, MacDonald WA, Deroo BJ, Kidder GM and Mann MRW (2012) Compromised fertility disrupts Peg1 but not Snrpn and Peg3 imprinted methylation acquisition in mouse oocytes. Front Gene. 3:129. doi: 10.3389/fgene.2012. 00129
This article was submitted to Frontiers in Epigenomics, a specialty of Frontiers in Genetics.

Copyright (c) 2012 Denomme, White, Gillio-Meina, MacDonald, Deroo, Kidder and Mann. This is an open-access article distributed under the terms of the Creative Commons Attribution License, which permits use, distribution and reproduction in other forums, provided the original authors and source are credited and subject to any copyright notices concerning any third-party graphics etc. 